\title{
Occurrence of Rhynchosporium secalis (Oud.) J. J. Davis on spring barley and winter rye in Finland
}

\author{
KAIHO MÄKELÄ \\ University of Helsinki, Department of Plant Pathology
}

Received April 18, 1974

\begin{abstract}
This study was carried out on Rhynchosprium secalis (Oud.) J. J. Davis occurring on spring barley, winter rye and couch grass (Agropyron repens (L.) PB) in Finland. The results were obtained from samples of barley (c. 860 samples) and rye (c. 200 samples) gathered in fields during the growing season throughout the country in 1971-1973. The samples (c. 170 samples) of Agropyron repens were collected in fields and the borders of fields.

The fungi of all the samples were examined by microscope and cultures and inocolation tests were used as well.

Rhynchosporium secalis was observed to occur commonly on spring barley throughout the country from Helsinki to Lapland. The fungus was observed in about 30 per cent of the fields and in below 60 per cent of the localities examined. Leaf blotch was commoner on sixrowed barley than on two-rowed barley. The fungus sometimes attacked a field in great profusion.

$R$. secalis was observed in below 50 per cent of the winter rye samples and in below 70 per cent of the localities examined. The fungus occurred commonly in the southern part of Finland and was found also in Lapland (Inari, $69^{\circ} \mathrm{N}, 27^{\circ} \mathrm{E}$ ). Spores of the fungus were most abundant in the leaves of rye in spring and in early summer.

$R$. secalis was observed rather scarce (in over 10 per cent of fields and in over 25 per cent of the localities examined) on Agropyron repens throughout the country.

A high degree of host specialisation has been found within the species $R$. secalis. Two isolates from spring barley and from winter rye were pathogenic to their original host only.
\end{abstract}

\section{Introduction}

Rhynchosporium secalis (Oud.) J. J. Davis causes leaf blotch disease of barley, rye and certain gresses (CAldwell 1937, Sprague 1950). The fungus has been observed to occur in the temperate zones of all continents (ANon. 1962). The fungus has been known for a long time (Frank 1897, Heinsen 1901, JøRSTAD 1930). Leaf blotch became a major disease of barley during the early $1960 \mathrm{~s}$ e.g. in Britain (KING 1972) and in Norway (HANsen and Magnus 1969). 
In Finland $R$. secalis has been rather insignificant up to the present, though it has not been studied in any detail. The fungus occurred in numerous spring barley fields in northern Finland in 1965 (TALvia 1966). MäkEL found $R$. secalis in about $1 / 4$ of the spring barley fields examined, the majority of which were located in the southern and central pars of the country.

$R$. secalis occurred also in rye, but is generally insignificant (BROoKs 1928, Jørstad 1930, ZwATZ 1967). To be sure there is information on crop damage which the fungus causes in the Soviet Union (PrIssyajNyUK 1931), Switzerland (MüLler 1953) and Tyrkey (BREMER et al. 1948).

On grasses the diffusion of the fungus is confined primarily to natural species (SPRAgUe 1950). Also in Finland $R$. secalis was not positively identified on cultivated grasses at all. On native grasses the fungus was observed rather scarce on Agropyron repens (L.) PB. and sporadically on Bromus inermis Leyss. (MÄKELÄ 1972 b).

This study is part of a research project dealing with spot diseases on cereals with the pathogens causing these diseases (cf. Mäkelä $1972 \mathrm{a}, 1972$ b). The purpose of the present study is to clarify the occurrence of Rhynchosporium secalis on spring barley, winter rye and couch grass. The study is based on samples that were gathered in farmers' fields throughout the country over a three year period $(1971-1973)$. Also an initial attempt was made to clarify the physiological specialization of $R$. secalis.

It is important to sort out these questions for the reason that in southern Finland pure cereal cultivation represents an increasing trend and croprotation is becoming less common. Spring barley is one of our most important cultivated plants and it thrives even in the northern parts of the country. In 1972 it accounted for about $17 \%$ of the country's field area (2665 000 ha). The proportion of winter rye is showing a corresponding decrease, amounting to about $2 \%$ in the same year. It is chiefly cultivated in the southern parts of the country (Statistic. Yearb. Finl. 1972).

\section{Material and methods}

The samples of spring barley were gathered in 157 fields in 1971, in 367 fields in 1972 and in 333 fields in 1973 (Table 1). They were present all over the country, the mojority being located in the southern and central parts of the country. About $\mathbf{8 0}$ per cent of these were six-rowed barley and about 20 per cent were two-rowed barley.

The samples of winter rye in 1972 came from 105 localities, the total samples numbering 203, chiefly from the southern parts of Finland (Table 1). The bulk were gathered at a growth stage when the grain was milky ripe, chiefly from late July to early August (20 July - 18 Aug., 1971; 16 July -8 Aug., 1972; 21 July - 14 Aug., 1973). The samples of winter rye were gathered in May also. Also observations of appearance of diseases were made in fields during the entire growing season.

As a rule it was attempted to take the representative samples from large areas of the field. In other respects no selecation was made. In most cases the variety remained unknown. 
The samples of Agropyron repens (c. 170 samples) were collected in fields and the borders of fields in many localities throughout the country (Table 1).

The leaves were checked for diseases by ocular examination on the basis of symptoms. For all the samples the fungi were examined by microscope. One-spore cultures of the fungus were made on PSA. Petri-dishes were kept under humid counditions at $+10^{\circ} \mathrm{C}$ (CAldwell 1937, Schein and Kerelo 1956).

Physiologic specialization of the fungus was researched with two isolates from six-rowed sprinh barley (one in Porvoo, the other in Loimaa) and two isolates from winter rye (one in Hollola, the other in Tuusula). Inoculation tests were performed on the different species of cereals (two-rowed barley cv. Balder, six-rowed barley cv. Otra, winter rye cv. Ensi, spring wheat cv. Norröna, oats cv. Pendek). The cereals were grown to a height of about $10-$ $15 \mathrm{~cm}$ in steriled quartz sand under laboratory conditions. The plants were inoculated with a spore suspension prepared in distilled water with conidia produced on potato sucrose agar. After inoculation the plants were kept under humid conditions at $+10^{\circ} \mathrm{C}$ for a period of 21 days.

\section{Climate and weather}

The following information on weather conditions is based on climatological data compiled by the Finnish Meteorological Institute (Anon. 1971, 1972 a, 1973).

1971. The weather in spring and summer was characterised by the alternation of one or two week periods of exceptional cold or heat. There was very little precipitation in spring and early summer. Also in July and the latter parts of August there was little rain, particularly in southern Finland.

1972. The weather during the growing period was exceptionally warm throughout the country. Precipitation conditions varied greatly in different parts of the country. There was little rain in May in southern Finland and in Ostrobothnia. Also in June there was little rain except in Satakunta and northern Ostrobothnia. In August there was quite a lot of rain in southern and central Finland.

1973. Throughout the country the entire spring and summer from May to August was exceptionally warm. During the entire growing period the amounts of precipitation were smaller than normal in most of central and southern Finland as well as in Lapland. There was especially light precipitation in July. Uusimaa and Kymenlaakso in particular suffered from draught (Meteorl. Yearb. Finl. 1971, 1972, 1973).

Results

Spring barley

Rhynchosporium secalis was encountered on barley throughout the country from Helsinki to Lapland (Sodankylä) (Fig. 1). The fungus was found in the following 143 localities (cf. Heikinheimo and RaAtikainen 1971). 


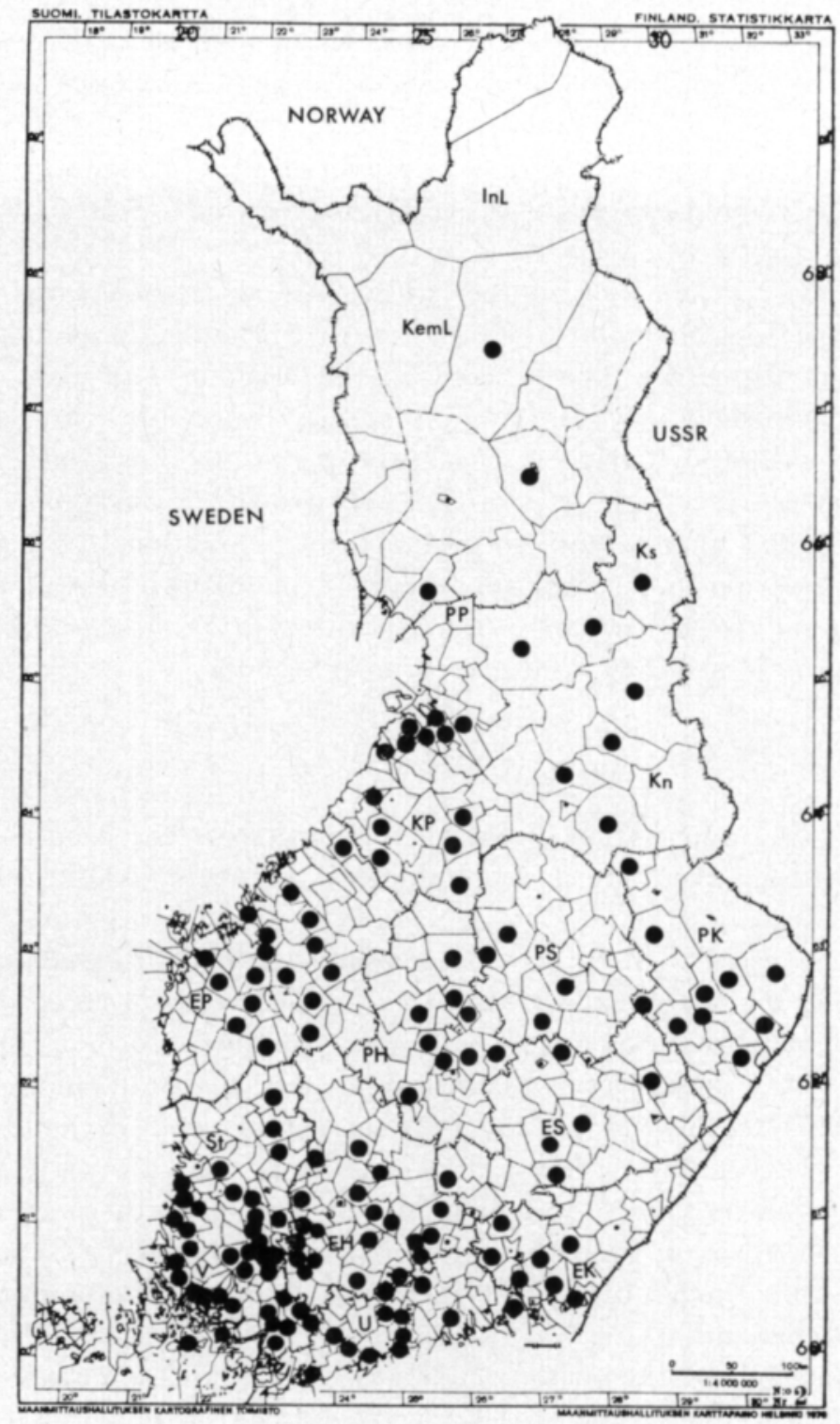

Fig. 1. The origin of Rhynchosporium secalis on spring barley in 1971-1973.

V: Halikko, Kalanti, Karkkila, Kiikala, Kodisjoki, Kuusjoki, Koski T1, Laitila, Lemu, Masku, Muurla, Nauvo, Parainen, Perniō, Piikkiō, Pōytyä, Raisio, Suomusjärvi, Vehmaa;

U: Anjala, Helsinki, Kirkkonummi, Mäntsälä, Nurmijärvi, Porvoo mlk., Pyhtää, Siuntio, Snappertuna, Vantaa, Tuusula;

EK: Sippola, Vehkalahti, Virolahti;

St: Alastaro, Eurajoki, Huittinen, Hämeenkyrö, Ikaalinen, Keikyä, Kokemäki, Kullaa, Köyliö, Loimaa, Loimaa mlk., Luvia, Mellilä, Metsämaa, Oripää, Parkano, Punkalaidun, Rauma, Vampula, Yläne; 
EH: Asikkala, Forssa, Hauho, Hausjärvi, Hollola, Humppila, Hämeenlinna, Iitti, Jokioinen, Jämsånkoski, Koski Hl, Kylmäkoski, Kärkölä, Loppi, Orivesi, Pälkäne, Sahalahti, Sysmä, Tuulos, Urjala, Vesilahti, Ylöjärvi;

ES: Enonkoski, Juva, Luumäki, Mikkeli, Ristiina;

EP: Alavus, Ilmajoki, Jalasjärvi, Koivulahti, Kuortane, Kurikka, Laihia, Lapua, Mustasaari, Ylihärmä, Ylista1o;

PH: Hankasalmi, Jyväskylä, Keitele, Konginkangas, Laukaa, Saarijärvi, Sumiainen, Uurainen, Viitasaari;

PS: Jäppilä, Pielavesi, Suonenjoki;

PK: Eno, Ilomantsi, Joensuu, Juuka, Kontiolahti, Liperi, Outokumpu, Tohmajärvi, Tuupovaara, Valtimo;

KP: Alahärmä, Alajärvi, Evijärvi, Kannus, Kärsämäki, Lappajärvi, Merijärvi, Munsala, Pattijoki, Piippola, Pyhäjoki, Pyhäjärvi, Revonlahti, Sievi, Ylivieska, Ähtävä;

Kn: Hyrynsalmi, Paltamo, Sotkamo, Suomussalmi;

PP: Kempele, Liminka, Lumijoki, Muhos, Pudasjärvi, Simo, Tyrnävä;

Ks: Kuusamo, Taivalkoski;

KemL: Sodankylä.

InLi: Inari (1974).

In 1971 and 1972 the fungus was found in $1 / 4$ of the samples collected in the fields and in 1973 it was found in a good $1 / 3$ of them. In $1971-1973$ the fungus was found in about $\mathbf{5 7}$ per cent of the licalities examined. In sixrowed barley, leaf blotch was in 1971 about thrice, in 1972 about twice as common as in two-rowed barley (cf. Table 1).

The occurrence of $R$. secalis varied grealtly in different localities and different fields (Table 1). In Satakunta (St), Ostrobothnia (EP) and North Karelia (PK), leaf blotch was found more frequently, while in Uusimaa (U) less than in the adjoining provinces. It often happened that of two adjoining plots of fields one would be healthy, one diseased. In 1972 in $1 / 3$ of the fields in which the fungus was observed there was high inoculation such that leaf blotch occurred in every barley individual. Most of the fields, however, were characterised by spotty occurrence of the disease.

Blotches caused by $R$. secalis were found in the leaves of barley through out the growing priod (Fig. 2). In yoyng shoots there was only a small number of blotches, located in the tips of the leaves, and these sometimes caused drying. The blotches were most plentiful in leaves that were at the strawing stage and in those which were ripe, in late July up to harvest time. At this time the same leaf was often marked by over 20 spots, the leaf being already completely destroyed. Also the development of the ears may be incomplete (Fig. 2). The dimensions of the spots (about 950 spots from 15 isolates were measured in 1971 and 1972) were: length (3.0) $11.7(40.0) \mathrm{mm}$, width (0.5) $2.4(8.0) \mathrm{mm}$; the samples contained an average 10.5 spots/leaf. The dimensions of the spores that had grown in the spots (1700 spores were measures from 74 isolates) were: length (9) 13.9 (40) $\mu$, width (1.6) 2.5 (4.0) $\mu$ (Fig. 2). Three and four-celled spores made up about $1 \%$ of the total. 


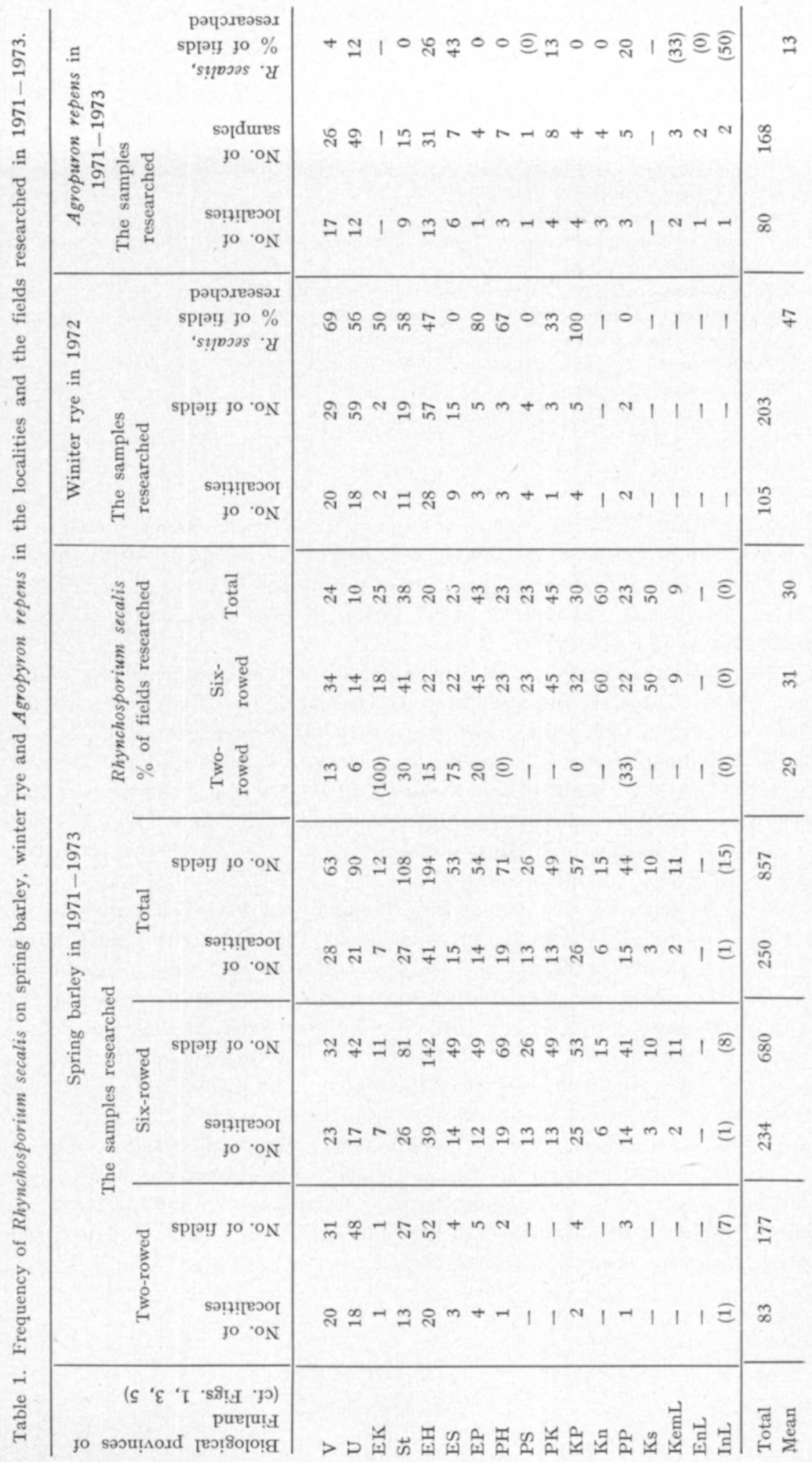



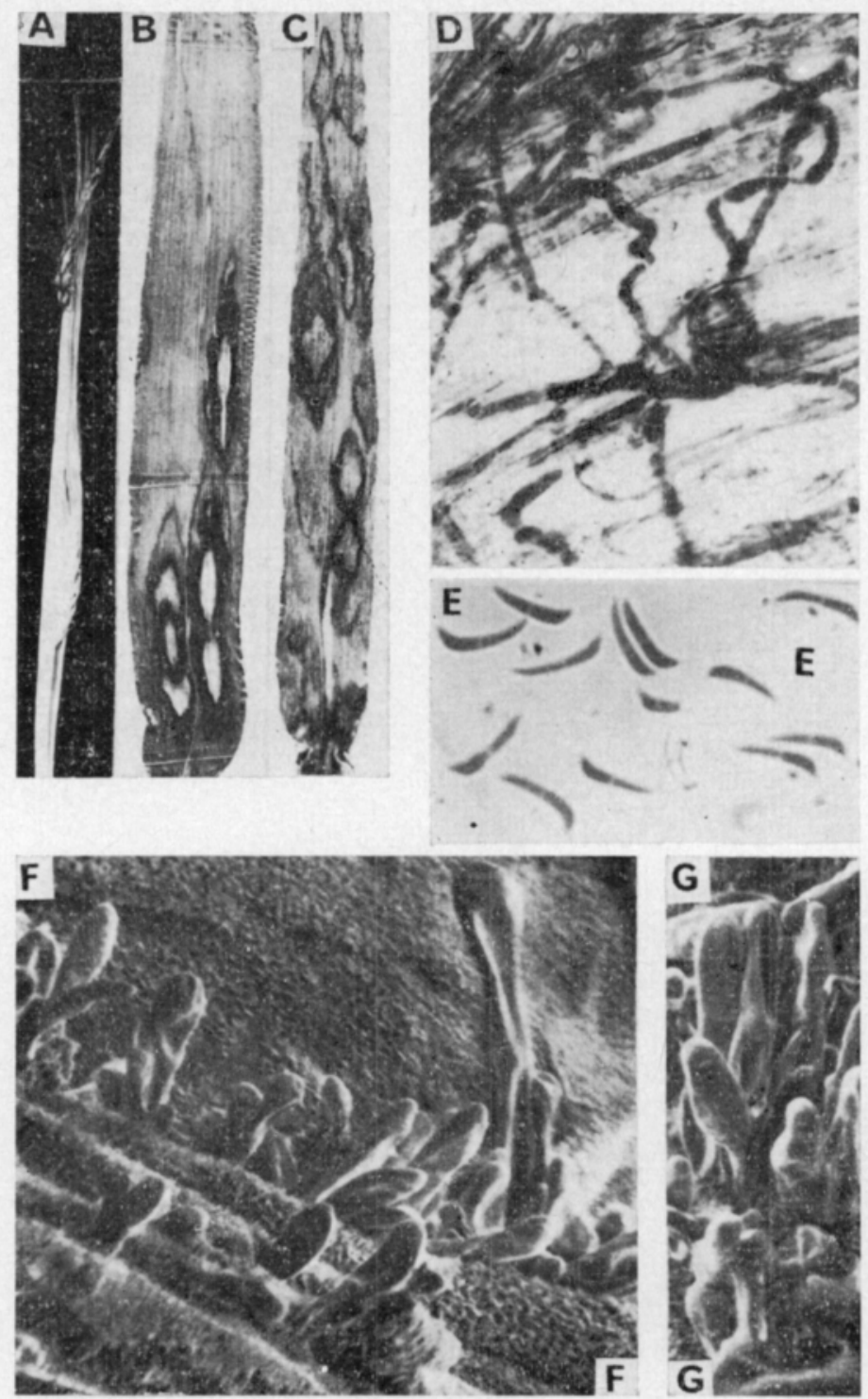

Fig. 2. Rhynchosporium secalis, A-E: on spring barley, F, G: on winter rye. A: The ear does not forme properly, B-C: blotches on leaves in late summer, D: germinating spores on the surface of inoculated leaf, E-G: conidia growing on the surface of leaf, F. G.: Janakkala 20.5. 1972. A: $x^{1} / 3$ B, C: $x$ 1, D, E: $x 700$, F: $x 2000$, G: $x 3000$, F. G: SEM, Viikki.

\section{Winter rye}

Rhynchosporium secalis was commonly encountered in 1972 in the southern and western parts of the country, while it was comparatively rare in the eastern parts, apparently owing to weather counditions (Fig. 3). Also in 1973 a realiable picture of the occurrence of the species on rye was not obtained owing to draught and early ripening. The northernmost locality were $R$. secalis has been encountered in Finland is Inari (Muddusniemi; 22. July, 1968, 28. July, 1969). The fungus turned up in about $47 \%$ of the samples (approx. 200 samples) 


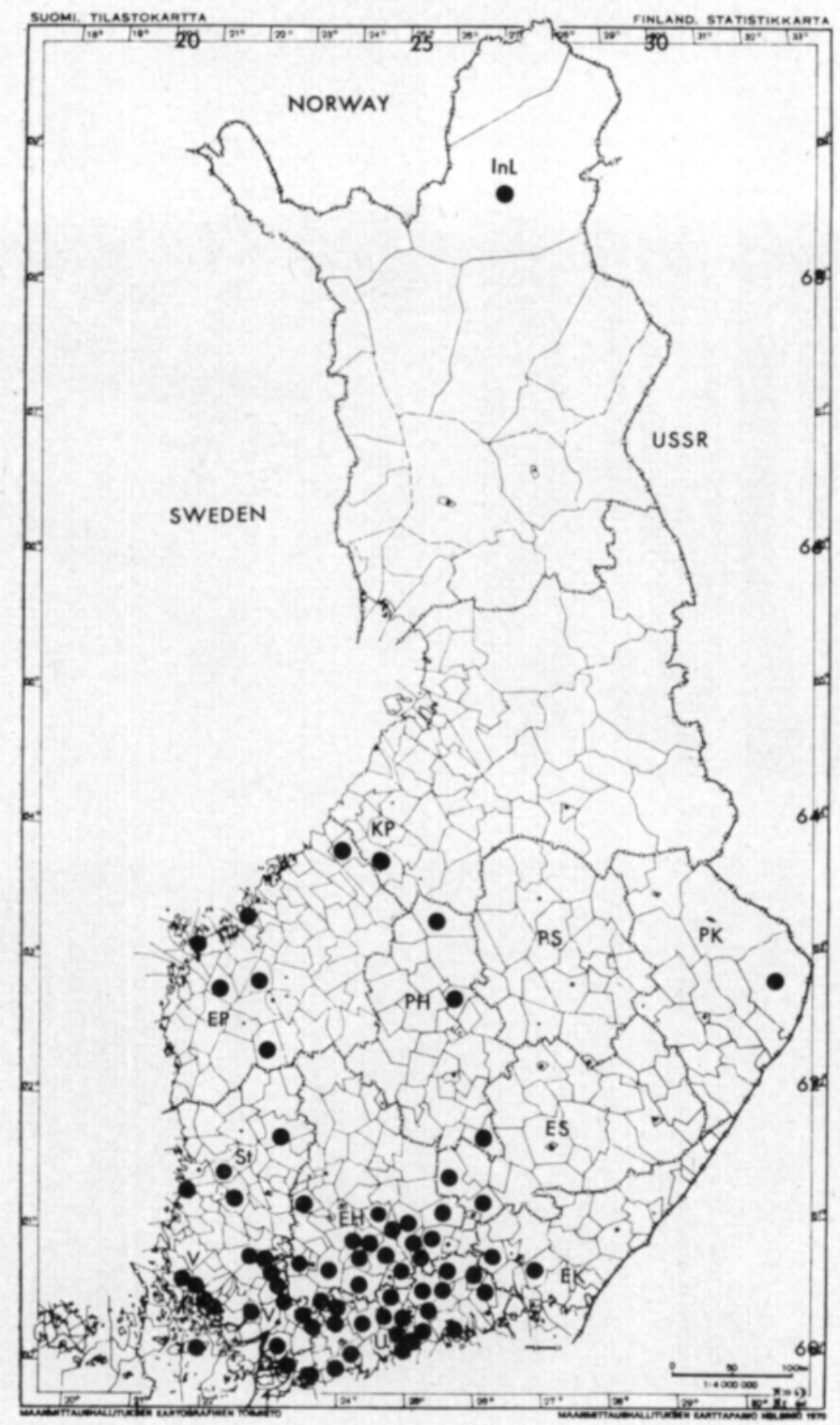

Fig. 3. The origin of Rhynchosporium secalis on winter rye in 1972.

V: Kiikala, Koski Tl, Kuusjoki, Masku, Mietoinen, Nauvo, Nummi, Paimio, Perniö, Pusula, Raisio, Suomusjärvi, Tenhola, Vehmaa, Vihti;

U: Artjärvi, Helsinki, Helsinkin mlk., Hyvinkää, Inkoo, Lapinjärvi, Mäntsälä, Nurmijärvi, Orimattila, Pornainen, Porvoo mlk., Pukkila, Sipoo, Siuntio, Snappertuna, Vantaa, Tuusula;

EK: Sippola;

St: Ikaalinen, Kokemäki, Kullaa, Loimaa mlk., Luvia, Mellilä, Oripää;

EH: Asikkala, Hausjärvi, Hattula, Hauho, Heinola mlk., Hollola, Hämeenlinna, Iitti, Janakkala, Jokioinen, Koski Hl, Kärkőlä, Lammi, Loppi, Renko, Somerniemi, Sysmä, Tammela, Tuulos, Vesilahti;

ES: Joutsa;

EP: Jalasjärvi, Laihia, Koivulahti, Ylistaro;

PH: Konginkangas, Pihtipudas;

PK: Ilomantsi;

KP: Kannus, Munsala, Sievi;

InL: Inari (1968, 1969). 

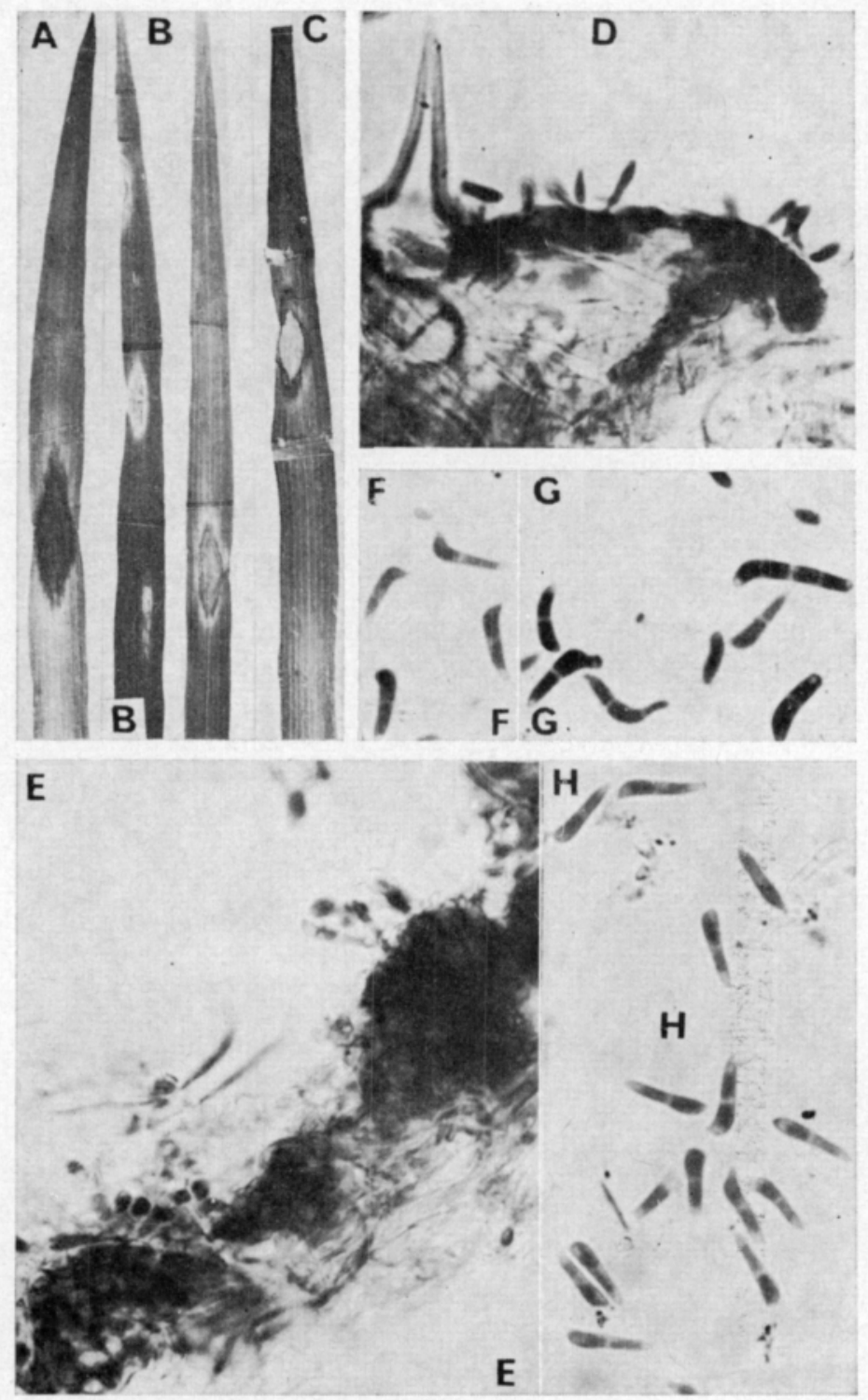

Fig. 4. Rhynchosporium secalis on winter rye in 1972. A-C: blotches on leaves in early summer, D, E: sporulating sclerotia on the surface of leaves, D: Hausjärvi 15. VI, E: Mellilä 1.VI, F-H: conidia, F: Tenhola 24. V, G: Snappertuna 27. V, H: Tammela 1. VI. A-C: x 1, D-H: x 700.

collected in fields and in about $69 \%$ of the localities examined in 1972 (Table 1). $R$. secalis was found in the following 72 localities (cf. Heikinheimo and RaAtiKAINEN 1971).

Spots caused by $R$. secalis were found on rye from early spring to harvest time. The spots were most plentiful in May and June. The fungus was also observed to be pernicious to shoots. Ordinarily the spots occurred at the base of the leaf and only rarely at its sheath.

In young shoots $R$. secalis caused browning of the tips, which often extended 
half way up the leaf. It also happened that the entire leaf turned yellow and dried up. The young spots were greyish green and they were surrounded by a dark or violet-brown, thin margin. Later on the centre of the spot turned light brown and the margin widened becoming brown in colour (Fig. 4). In leaves gathered at the straw stage the spots were organgish-grey or light brown and a reddish tinge was often perceptible in them. A distinct margin was rarer than at the shoot stage. At the time rye usually ripens the spots had become indistinct, appearing as spots that were darker than their surrounding areas. The dimensions of the spots (about 500 spots measured from 26 isolates) were: length (1.0) $10.9(33.0) \mathrm{mm}$, width (0.5) $2.3(9.0) \mathrm{mm}$; the samples contained an average 4 spots/leaf. The dimensions of the spores that had grown on the leaves (900 spores were measured from 36 isolates) were: length $(10.0)$ $15.0(29.0) \mu$, width (2.0) 3.1 (6.0) $\mu$ (Fig. 4). Spores occurred abundantly in the spots in spring and early summer, whereas at the end of July there were only a few spores per spot.

In addition to Rhynchosporium secalis several other parasites such as rust and smuts, Erysiphe graminis DC., Helminthosporium and Septoria species wete observed to grow at the same time on the leaves of both barley and rye.

Inoculation experiments

The two isolates of Rhynchosporium secalis obtained from barley inoculated only barley.

The two isolates of $R$. secalis obtained from rye caused infection only in rye. The spore production of the fungus was plentiful in the inoculated leaves of both barley and rye (Fig. 2).

This small number of initial laboratory experiments support the observations made in the field. In the summer of 1972 in the trial fields at the Hankkija Plant Breeding Institute in Hyrylä the rye plots were severely infected by $R$. secalis whereas in the nearby barley plots the disease was not observed at all.

\section{Couch grass (Agropyron repens)}

Rhynchosporium secalis was encountered on couch grass (Agropyron repens) throughout the contry from Helsinki to Lapland (Inari). The fungus was found in the 21 following localities (cf. Heikinheimo and RaAtikainen 1971).

$R$. secalis turned up in about $13 \%$ of the samples (approx. 170 samples) and in about $26 \%$ of the localities examined (Table 1). The fungus occurred primarily in spring and early summer. The spots which $R$. secalis caused on the leaves were bluish grey or greyish brown in colour and the margins were dark or violet brown. The dimensions of the spots (60 spots were measured) were: length $7.4 \mathrm{~mm}$ and width $2.5 \mathrm{~mm}$. The dimensions of the spores which had grown in the spots (110 spores were measured) were: length (8.3) 13.6 (19.0) $\mu$ and width (2.2) $2.5(4.5) \mu$. R. secalis was not isolated from couch 


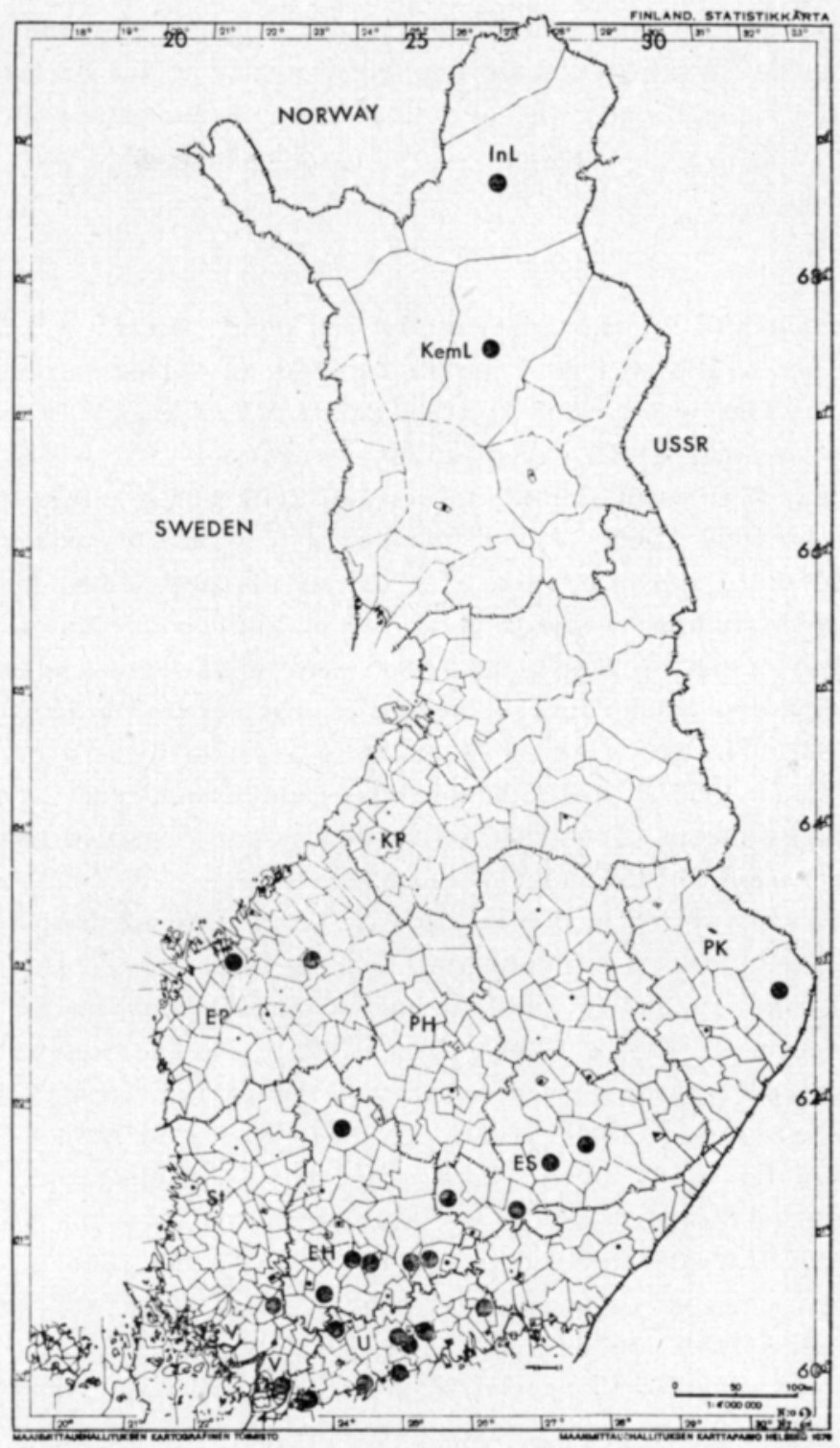

Fig. 5. The origin of Rhynchosporium secalis on Agropyron repens in 1971-1973.

V: Koski Tl;

U: Helsinki, Kerava, Kirkkonummi, Lapinjärvi, Pornainen, Snappertuna;

EH: Hollola, Hämeenlinna, Koski Hl, Tammela, Tyrväntö, Ruovesi, Sysmä;

ES: Juva, Mikkeli, Mäntyharju;

PK: Ilomantsi;

PP: Tenhola;

KemL: Sodankylä;

InL: Inari.

grass. The occurrence of the fungus in much smaller amounts on couch grass than on barley or rye points to the marked specialisation of the fungus. Indeed, couch grass is one of the commonest field weeds throughout the country 
(Mukula et al. 1969). The same notion is also supported by the observation, made in 1972, that in a field of barley in which nearly all the barley individuals were infected by the fungus, the abundant couch grass that grew there as a weed was healthy.

\section{Discussion}

During the period in which this study was being carried out, 1971-1973, Rhynchosporium secalis was common in Finland on spring barley as well as on winter rye. This was true in spite of the fact that in the growing periods in these years the weather was exceptionally warm and dry (cf. p. 105). It is known that the fungus thrives in humid, rainy and cool weather (CALDWELL 1937, 1968 , SKoropad 1957, 1966). The occurrence of $R$. secalis on winter rye (Secale cereal L.) and on Agropyron repens (L.) PB in Lapland (Inari, $69^{\circ} \mathrm{N}, 27^{\circ} \mathrm{E}$ ) indicates that the fungus is able to stand a long and severe winter. In Norway, too, the fungus occurs on Agropyron repens and on Hordeum vulgare L. as far as Tromsa (JøRSTAD 1930) and in Iceland also it occurs on Hordeum vulgare (JøRSTAD 1962). The mycelium of $R$. secalis was found to be very resistant to freezing (BARTELS 1928). On the leaves of rye and couch grass small stromata were observed by means of which the fungus was also observed to persist from one growing period to the next (CALDWELL 1937).

In Finland only spring barley is cultivated and thus infection cannot occur from over winter plants as in countries such as Denmark (STAPEL 1960) and Britain (HABGood 1972). In Finland barley stubble may be an important source of infection (cf. Evans 1969, Polley 1971). For the present no evidence has been received regarding seed spreading; regarding information for other countries (cf. SKoropad 1959, Habgood 1971, KAY and OWEN 1973 a).

Finnish isolates of $R$. secalis show strict host specialisation. The results paralelled those obtained in numerous other studies (CALDWEll 1937, Müller 1953, Owen 1958, Kajiwara and Iwata 1963, Kajiwara 1968). On the other hand the opposite conclusion has also been reached (BARTELs 1928, Schein 1958, Kay and OWen 1973 b, Wilkins 1973).

KAY and OwEN (1973 b) proved $R$. secalis isolates from Agropyron repens and from rye to be pathogenic to their original host and to barley. This result is interesting from the standpoint of the conditions prevailing in Finland since the same plants are common here (Anon. 1972 b, Mukula et al. 1969). $R$. secalis was more prevalent on six-rowed than on two-rowed barley varieties (cf. Hansen and Magnus 1973). Physiological races of the fungus have been observed to occur on barley in recent years in Britain (Fowler and OwEN 1971, Williams and Owen 1973) and in Norway (cf. Hansen and Magnus 1969, 1973).

\footnotetext{
Acknowledgements. - I express my sincere thanks to Mr. Reijo Vanhanen, M.Sc., who examined part of the materials in $\mathbf{1 9 7 2}$ in his pro gradu study at the University of Helsinki. I am thankful to Mr. Leo Mustonen, Mr. Aarne Kurppa, Mrs. Hilkka Koponen and Mrs. Sirpa Palojärvi for their technical assistance, e.g. in collecting plant specimens and measuring spores. I am grateful to the University of Helsinki and to the National Research Council for Agriculture and Forestry for their financial assisțance.
} 


\section{REFERENCES}

ANON. 1962. Rhynchosporium secalis (Oudem.) Davis. Distribution Maps of Plant Diseases no. 383 , ed. 2 .

Bartels, F. 1928. Studien über Marssonina graminicola. Forsch. Gebit Pfl.krankh. Immunität Pfl.reich 5: 73-114.

Bremer, H., Ismen, H., Karel, G., Özkan, H. \& Özkan, M. 1948. Beiträge zur Kenntnis der parasitischen Pilze der Türkei. Tul. III. Rev. Fac. Sci. Univ. Istanbul, Ser. B, 8, 1: $1-53$

Brooks, F. T. 1928. Observations on Rhynchosporium secalis (Oud.) Davis, leaf blotch of barley and rye. New Phytologist 27, 4: 215-219.

Caldwell, R. M. 1937. Rhynchosporium scald of barley, rye and other grasses J. Agric. Res. 55: 175-198.

Evans, S. G. 1969. Observations on the development of leaf blotch and net blotch of barley from barley debris, 1968. Pl. Path. 18: 116-118.

Fowler, A. M. \& OWEN, H. 1971. Studies on leaf blotch of barley (Rhynochosporium secalis). Trans. Brit. Mycol. Soc. 56: $137-152$.

Frank, A. B. 1897. Uber die Zerstörungen der Gerste durch einen neuen Getreidepilz. Wochenschr. Brauerei. 14: 518-520.

Habgood, R. M. 1971. The transmission of Rhynchosporium secalis by infected barley seed. Pl. Path. 20: $80-81$.

- - 1972. Resistance to Rhynchosporium secalis in the winter barley cultivar Vulcan. Ann. Appl. Biol. 72, 3: 265-271.

Hansen, L. R. \& Mngnus, H. A. 1969. Leaf spot fungi on barley in Norway. Norwegian Pl. Protect. Inst., Div. Pl. Path., Vollebekk. Rep. No. 42.

- - \& Magnus, H. A. 1973. Virulence spectrum of Rhynchosporium secalis in Norway and sources of resistance in barley. Phytopath. Z. 76: 303-313.

Heikinheimo, O. \& RaAtrkainen, M. 1971. The recording of localities of biological finds in Finland. Ann. Ent. Fenn. 37, 1 a: 1-27.

Heinsen, E. 1901. Beobauchtungen über den neuen Getreidepilze Rhynchosporium graminicola. Jahrb. Hamburg Wiss. Anst. 18, 3: 43-55.

Jørstad, I. 1930. Beretning om plantesykdommer in land- og hagebruket. VI. Sykdommer på korn- og engvekster. 84 p. Oslo.

- 1962. Icelandic parasitic fungi apart from Uredinales. 72 p. Oslo.

KaJrwara, T. 1968. Comparative studies on the pathogenicity of barley and rye scald fungus Rhynchosporium secalis (Oud.) Davis. Bull. Nat. Inst. Agric. Sci. Tokyo Ser. C. 22: 259-268.

- - \& IwatA, Y. 1963. Studies on the strains of the barley scald fungus, Rhynchosporium secalis (Oud.) Davis. Bull. Nat. Inst. Agric. Sci., Tokoy, Ser. C, 15:1-73.

KAY, J. G. \& Owen, H. 1973 a. Transmission of Rhynchosporium secalis on barley grain. Trans. Brit. Mycol. Soc. 60, 3: 405-411.

- 1973 b. Host range of Rhynchosporium secalis. Trans. Brit. Mycol. Soc. 60, 3: 413-422.

KING, J. E. 1972. Surveys of foliar diseases of spring barley in England and Wales 1967-70. Pl. Path. 21:23-35. 
Mukula, J., RaAtikainen, M., Lallukka, R. \& RaAtikainen, T. 1969. Composition of weed flora in spring cereals in Finland. Ann. Agric. Fenn. 8: 59-110.

Müller, E. 1953. Versuche mit dem Rhynchosporium-Schorf von Gerste und Roggen. Ann. Agric. Suisse 54 N.S. 2: 739-743.

MÄKELÄ, K. 1972 a. Leaf spot fungi on barley in Finland. Acta Agr. Fenn. 124, 3: 1-23.

- 1972 b. Rhynchosporium species on Finnish grasses. Karstenia 13: 23-31.

OwEn, H. 1958. Physiologic specialization in Rhynchosporium secalis. Trans. Brit. Mycol. Soc. 41, 1: $99-108$.

Polley, R. W. 1971. Barley leaf blotch epidemics in relation to weather conditions with observations on the overwintering of the disease on barley debris. Pl. Path. 20: 184190.

Prissyajnyuk, A. A. 1931. (Contributions to the study of fungous diseases of field crops in the Lower Volga region.) Pl. Protect. Leningrad 7: 323-337. (Ref. Rev. Appl. Mycol. 11: $281-282)$.

Schern, R. D. 1958. Pathogenic specialization in Rhynchosporium secalis. Phytopath. 48: 477-480.

- - \& Kerelo, J. M. 1956. Culturing Rhynchosporium secalis. Pl. Dis. Rep. 40: 814-815.

SKoropad, W. P. 1957. Temperature and humidity relationships in securing infection of barley with Rhynchosporium secalis. Phytopath. 47:32-33.

- - 1959. Seed ans seedling infection of barley by Rhynchosporium secalis. Phytopath. 49: $623-626$.

- - 1966. Sporulating potential of Rhynchosporium secalis on naturally infected leaves on barley. Can. J. Pl. Sci. 46, 3: 243-247.

Sprague, R. 1950. Diseases of cereals and grasses in North America. 538 p. New York.

Stapel, C. 1960. Det falske saedskrifte og dets plantepatologiske betydning Norsk. Jordbr. Forskn., 1960, Suppl. 1: 274-279.

Talvia, P. 1966. Kasvitautien esiintyminen 1965. Maatal. ja Koetoim. 20: 214-221.

WiLkıns, P. 1973. Infection of Lolium multiflorum with Rhynchosporium species. Pl. Path. 22: $107-111$.

Williams, R. J. \& OWEn, H. 1973. Physiologic races of Rhynchosporium secalis on barley in Britain. Trans. Britt. Mycol. Soc. 60, 2: 223-234.

ZwATZ, B. 1967. Marssonina-Blattfleckenkrankheit an Gerste und Roggen (Rhynchosporium secalis). Pflanzenarzt 20, 1:5-6. (Ref. Rev. Appl. Mycol. 46: 364.) 


\title{
Selostus
}

\section{Rhynchosporium secalis (Oud.) J. J. Davis-sienen esiintyminen ohralla, rukiilla ja juolavehnällä}

\author{
KAIHO MÄKELÄ
}

Yliopiston kasvipatologian laitos, Viikki

Tutkimuksessa selvitettiin sienen levinneisyyttä ja biologiaa. Tulokset perustuvat pääosin vv. 1971-1973 kautta maan viljelijäin pelloilta kasvukauden aikana kerättyihin näytteisiin (yht. n. 860 ohranäytettä 250 paikkakunnalta ja 200 ruisnäytettä 105 paikkakunnalta). Lisäksi tutkittiin suurelta osin samoilta pelloilta ja pientareilta kerättyjä juolavehnännåytteitä (yht. 170 näytettä 80 paikkakunnalta).

Kaikki näytteet tutkittiin silmävaraisesti ja mikroskooppisesti. Lisäksi viljeltiin sientä keinoalustalla ja tehtiin saastutuskokeita laboratorio-oloissa.

Rhynchosporium secalista esiintyi ohralla yleisenä kautta maan. Naapurialueitaan runsaampana tautia esiintyi näinä vuosina. Pohjois-Karjalassa, Etelä-Pohjanmaalla ja Satakunnassa, vähäisemmässä määrin taas Uudellamaalla. Sientä todettiin keskin. n. 1/3 tutkituista pelloista ja alle $60 \%$ tutkituista paikkakunnista. Tauti oli yleisempi monitahoisissa kuin 2tahoisissa ohralajikkeissa. Runsaimmillaan oli tauti korsiasteella jo tuleentuvassa viljassa. V. 1972 oli n. 1/3:ssa viljelmistä, joilla tautia todettiin, saastunta niin ankaraa, että jokaisessa ohrayksilössä esiintyi taudin laikkuja. Pääosalle peltoja oli kuitenkin ominaista, että tautia esiintyi laikuittain.

Rukiilla todettiin tautia n. 1/2:lla tutkituista näytteistä. Ja n. 70\% tutkituista paikkakunnista. Sientä esiintyi yleisenä maan eteläisisä osissa, joskin sitä on todettu Lappia myöten. Tautia esiintyi kautta kasvukauden. Runsaimmillaan se oli touko-kesäkuussa vioittaen varsinkin nuoria oraita.

Juolavehnällä (Agropyron repens (L.) PB.) sientä esiintyi kautta maan n. $13 \%$ :ssa tutkituista näytteistä ja n. 1/4 tutkituista paikkakunnista.

Ohralta ja rukiilta eristetyt Rhynchosporium secalis-kannat (kaksi kantaa kummaltakin) saastuttivat vain isäntäkasvejaan. Tutkimuksia on kuitenkin jatkettava ennen kuin sienen fysiologisesta erikoistumisesta voidaan meidän oloissamme sanoa mitään varmaa. 